\title{
Elucidation of a Peculiar Phenomenon of Voltage Measuring at a Substation
}

\author{
Kouya Takafuji Member (Chubu Electric Power Co., Inc.) \\ Takashi Satou Member (Chubu Electric Power Co., Inc.) \\ Hisanori Itou Member (Chubu Electric Power Co., Inc.) \\ Isao Kouda Member (Chuden CTI CO., LTD) \\ Toshiaki Haba Non-member (Chuden CTI CO., LTD) \\ Atushi Satake Member (Chuden CTI CO., LTD) \\ Eiichi Haginomori Member (Chuo University)
}

Keywords: voltage drop, saturation of voltage transformer, line arrester, continuous discharge

\section{Introduction}

An automatic fault-recorder installed in a substation of Chubu Electric Power Company detected a peculiar phenomenon that busbar voltage fell to around $20-30 \%$ of the nominal value for a short time (about 8-10 cycles) though the electric current didn't change during the periods. The penomenon was recorded several times.

We assumed various causes of this phenomenon, and conducted simulations with an analog-type electric power simulator. However, the phenomenon was not able to be identified through the simulation.

So we thought that it was not an actual phenomenon on the power system, but a phenominon on the measurement circuit of VT(voltage transformer) by saturation. and this was caused by lightning strokes to the transmission line with lightening arresters, which have been increasingly installed to the lines in recent years. Then the simulation for the VT was conducted by EMTP. As a result, the same phenomenon as recorded was able to be observed, and the validity of the estimated cause was confirmed.

\section{Occurrence Mechanism of the Phenomenon}

We estimated the mechanism of the phenomenon from various situations as follows.

(1) Llightning struck the power line directly The record of Lightning Location System (LLS) shows that lightning struck the power line at the same time the phenomenon was recorded, which was eliminated by the line arrester.

(2) Lightning energy is supplied to VT as direct current by the effect of the line arrester In the power line equipped with the arrestor, lightining energy under the arrester's residual voltage is supplied to the power system as direct current.

The direct current can be temporally stored in the capacitance of the power system and then gradually discharged through NGR (neutral point earth resistance) and the VT neutral point.

(3) Iron core of VT was saturated by direct current, thus the secondary voltage of VT dropped VT has the feature that the secondary voltage drops easily when its iron core is saturated because the primary leakage impedance is very large. The leakage impedance of the VT for $77 \mathrm{kV}$ bus is about $100 \mathrm{H}$, which is about 800 times compared with a $154 \mathrm{kV} / 77 \mathrm{kV}$ transformer.
(4) VT saturation continued by the continuous lightning discharge In this phenomena, the voltage drop continued by about 10 cycles. However, EMTP simulation shows that just a single stroke of lightning causes not 10 cycle drop, but only 2 or 3 cycle drop. On the ohter hand, NGR current of an fault-recorder shows that direct current was supplied continuously. Therefore, our estimation is that this direct current was supplied by "continuous discharge", which continued several hundred mili-seconds between lightning strokes. This is because a lot of lightnings occurred when the phenomenon was recorded.

\section{EMTP Simulation}

The simulation result of EMTP is shown below, which is almost the same as the recorded wave form.
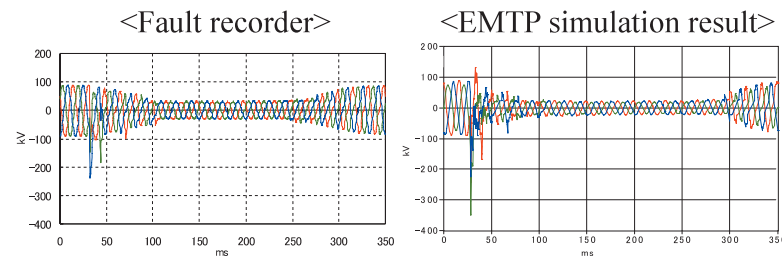

Fig. 1. EMTP simulation result-wave form of bus voltage

\section{Influence to Protection Relays}

On a short-circuit fault, the under-voltage relay (failsafe of the differential-current relay) or the directional-distance relay has a possibility of mal-operation. However, as the both cannot act at the same time, a trip due to mal-operation will never happen. On a ground fault, protection relays will not mal-operate because zerophase voltage and current caused by the phenomenon is limited to direct current or higher harmonics wave.

\section{Conclusion}

In this paper, we elcidated the cause of peculiar phenomenon of the voltage measuring at a substation, and found that the phenomenon doesn't negatively affect the operation of protection relays. 


\section{変電所における計測電圧特異現象の解明}

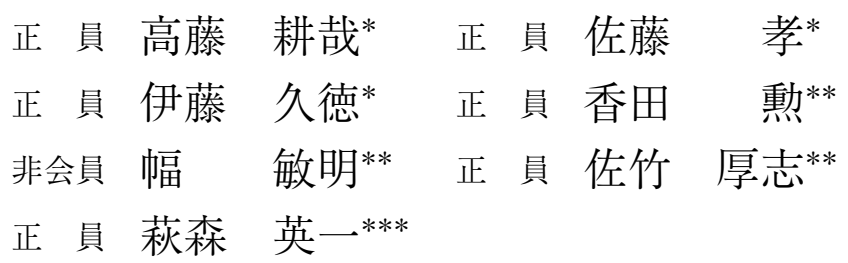

\section{Elucidation of a Peculiar Phenomenon of Voltage Measuring at a Substation}

Kouya Takafuji*, Member, Takashi Satou*, Member, Hisanori Itou*, Member, Isao Kouda**, Member, Toshiaki Haba**, Non-member, Atushi Satake**, Member, Eiichi Haginomori***, Member

An automatic fault-recorder installed in a substation of Chubu Electric Power Company detected a peculiar phenomenon that bus-bar voltage fell to around 20-30\% of the nominal value for a short time (about 8-10 cycles) though electric current didn't change during the period. The phenominon was recorded several times.

In this paper, we analyzed the origin of this phenomenon and conducted simulations by EMTP. As a result, we estimated that this phenomenon occurred by the saturation of VT (voltage transformer), and this saturation caused by lightning strokes to the transmission line with line arresters, which have been increasingly installed in recent years. Moreover, we evaluated the influence of the phenomenon to protection relays.

キーワード: 電圧低下, VT 飽和, 送電線アレスタ, 連続放電

Keywords: voltage drop, saturation of voltage transformer, line arrester, continuous discharge

\section{1. はじめに}

近年，製造業等では，瞬時電圧低下に鋭敏な機器が多く使 用されてきており，瞬時電圧低下による社会的影響が益々 大きくなってきている。

このような状況の中, 中部電力管内 $77 \mathrm{kV}$ 系統において, 雷が多発している気象条件の中，電流が変化しないにも関 わらず，母線電圧が短時間（約 8 サイクル〜 10 サイクル程 度）20３0\%近くまで低下する特異現象が，複数回，自動 オシロ装置に記録された。

この時, 電圧低下を検出する警報リレーは動作したが, 保

\footnotetext{
*中部電力 (株)

于 461-8680 名古屋市東区東新町 1 番地

Chubu Electric Power Co., Inc.

1, Higashi-shin-cho, Higashi-ku, Nagoya 461-8681

**（株）中電シーティーアイ

干 455-0842 名古屋市港区稲永 2-1-80 稲永ビル

Chuden CTI CO., LTD

2-1-80, Inaei, Minato-ku, Nagoya 455-0842

*** 中央大学

于 112-8551 東京都文京区春日 1-13-27

Chuo University

1-13-27, Kasuga, Bunkyo-ku, Tokyo 112-8551
}

護リレーが動作していなかったため，現象を記録した変電 所において，保護リレーや自動オシロ装置の健全性を確認 したが異常は発見されなかった。

そこで, 中部電力が保有するアナログ型電力シミュレー 夕を使用して, 対象系統を模擬し, 様々な事象を想定して同 様の現象が発生するかシミュレーションを行ったが, 電流 が変化せずに電圧だけが低下する現象は確認されなかった。

このため, 本現象は, 電力系統側の現象ではなく, VT（計 器用变圧器）の飽和によって発生した計測回路の事象では ないかと考えた。そして，その飽和は，近年，整備が拡大 されてきている送電線アレスタ (避雷器) の動作によって 雷撃エネルギーがVTに供給されたため発生したものと推 定し，EMTPによるシミュレーション解析を行った。その 結果, ほほ実測值とおなじ現象を再現することができ, 推 定した発生原因の妥当性を確認することができた。

本稿では, 本現象の発生メカニズムと, その妥当性を確 認するため行ったシミュレーション結果, 本現象が発生し た場合に保護リレーへ与える影響について述べる。 


\section{2. 特異現象の概要}

\section{(i) 発生年月}

平成 8 年 7 月, 平成 16 年 2 月（中部電力 $\mathrm{M}$ 変電所） 平成 17 年 8 月（中部電力 $\mathrm{S}$ 変電所）

(ii) 気象棃れも雷が多数発生中。

(iii) オシロ装置記録Ｆig. 1 には, M 変電所のオシロ 装置が記録した波形を，Fig. 2 には，M 変電所 $77 \mathrm{kV}$ 系統 図とオシロ装置設置箇所を示す。Fig. 1 より, $77 \mathrm{kV}$ 母線電 圧が 3 相とも（Vr，Vs，Vt）10 サイクル程度継続して, 残 り電圧 20\%～30\%近くまで低下しているが，バンク二次電 流（Ir，Is，It）が変化（増加）していない。

(iv) 状況

(1) 警報リレー（UV）は動作したが，保護リレーによる

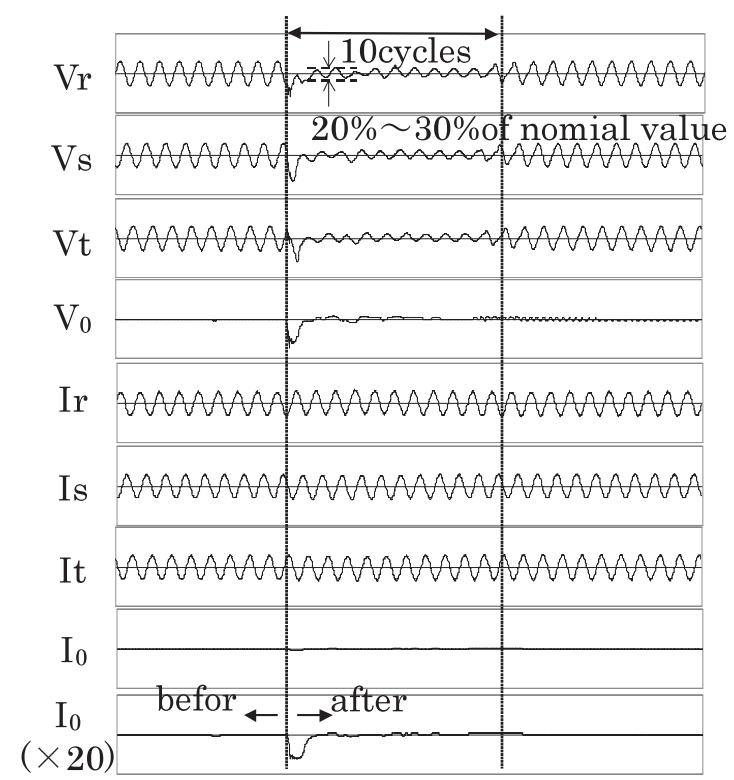

Fig. 1. Wave forms of voltage and current recorded in automatic fault-recorder (M Substation).

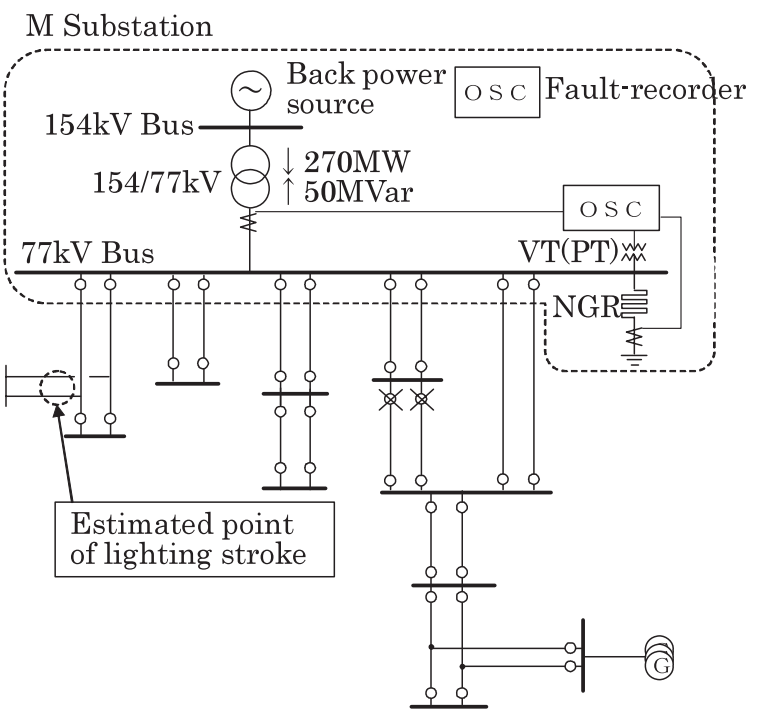

Fig. 2. Power system diagram (M Substation and related power system).
トリップは無かった。なお，後日，保護リレー，オシ ロ装置等を点検したが異常は無かった。

(2) 現象発生と同時刻に, 当該系統において, LLS（落 雷位置標定装置) の動作記録が多数残っていた。

\section{3. 電気回路理論に基づいた考察}

今回の現象の特徵的な事は, 電圧は異常に低下（電圧低 下 $70 \%$, 残り電圧 30\%）しているにもかかわらず, 故障電 流が流れていない（バンク二次電流に顕著な変化なし）こ とである。

この現象は, 電気回路理論上起こりえない事象であり, 以 下に考察を示す。

〈3・1〉 故障点インピーダンスが接続された場合

ここでは，現象発生時に，系統故障が発生したことを想 定した考察を行う。

Fig. 3 に $\mathrm{M}$ 変電所の $77 \mathrm{kV}$ 系統に, 故障点インピーダン

ス ZLx が接続される回路モデルを示す。

故障前のバンク二次電流 I2 は (1) 式, 故障後のバンク二 次電流 I2’は(2) 式で表される。

$$
\begin{aligned}
I 2 & =\frac{E s 1}{Z s 1+Z L 1} \cdots \ldots \ldots \ldots \ldots \ldots \\
I 2^{\prime} & =\frac{E s 1}{Z s 1+(Z L 1 \times Z L x) /(Z L 1+Z L x)}
\end{aligned}
$$

(2) 式の分母のうち $(Z L 1 \times Z L x) /(Z L 1+Z L x)$ は $\frac{Z L 1}{(Z L 1 / Z L x)+1}$ となり, (1) 式の分母のうち ZL1 と比較 すると

$$
Z L 1>\frac{Z L 1}{(Z L 1 / Z L x)+1}
$$

となる。

これはバンク二次電流が $I 2^{\prime}>I 2$ の関係にあることを示 している。

また, I2' - I2 (>0)の電流増加分が, 変圧器インピーダ

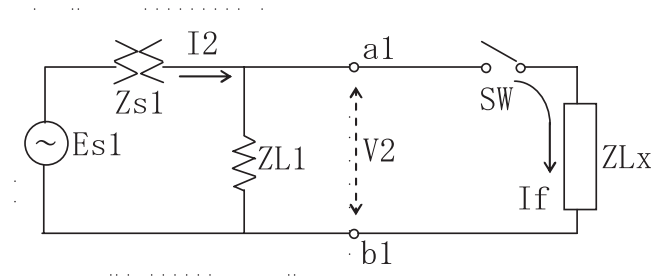

$$
\begin{aligned}
& \text { Es1：上位系統の電源 } \\
& \mathrm{Zs} 1 ： \mathrm{M} \text { 変電所バンクのインピーダンス } \\
& \mathrm{ZL} 1 ： \mathrm{M} \text { 変電所バンク以下の負荷インピーダンス } \\
& \text { ZLx：故障点インピーダンス } \\
& \text { I2：故障前のバンク二次電流 } \\
& \text { I2':故障後のバンク二次電流 } \\
& \text { If : ZLx へ流れる電流 } \\
& Z o=\frac{Z s \mid \times Z L 1}{Z s 1+Z L 1} \text { : 端子 } \mathrm{a} 1-\mathrm{b} 1 \text { から電源側インイーダンス }
\end{aligned}
$$

Fig. 3. Equivalent circuit model (Case of system fault). 
ンス $(\mathrm{Zs} 1)$ を流れることで電圧降下が生じ, バンク二次電 圧 V2 は低下する。

つまり，故障点インピーダンスが接続されればバンク二 次電圧は下がり，電流は増えることになる。

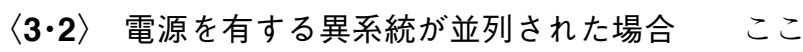
では，現象発生時に，電源を有する異系統が並列されたこ とを想定した考察を行う。

Fig. 4 に 変電所の $77 \mathrm{kV}$ 系統に, 電源を有する異系統 が接続される回路モデルを示す。

SW を閉じたときに流れる電流 I3 は，鳳ーテブナンの定 理を用いて，(3) 式のように表せる。

$$
I 3=\frac{V 2-V x}{\frac{Z s \times Z l}{Z s+X l}+\frac{Z x 1 \times Z x L 1}{Z x 1+Z x L 1}}
$$

$\mathrm{SW}$ を閉じたとき，I2 に変化はないため， M 変電所のバ ンク二次電流 $(\mathrm{I} 2+\mathrm{I} 3)$ に変化がないとすると, $\mathrm{I} 3=0$ で なければならない。この事から，I3＝0 として (3) 式を解 くと, $\mathrm{V} 2=\mathrm{Vx}$ となる。

これは, バンク二次電流の変化がないとすると, $\mathrm{M}$ 変電 所バンク二次電圧と異系統側の電圧が同じでなければなら ない。つまりバンク二次電圧にも変化があってはならない ことを表している。

以上の考察から, 本現象は, 電力系統側の事象でなく, 变 電所内の計測回路の事象である可能性が高いと考えた。

なお，本考察では，系統に負荷が投入されたケースを想 定していないが，非常に大きな負荷が投入された場合，無効 電力の影響で電圧だけ低下する現象が発生する可能性はあ るが, 今回の事象のように $20 \sim 30 \%$ も電圧低下が $100 \mathrm{~ms}$ 以上継続することは現実的に考えにくい。

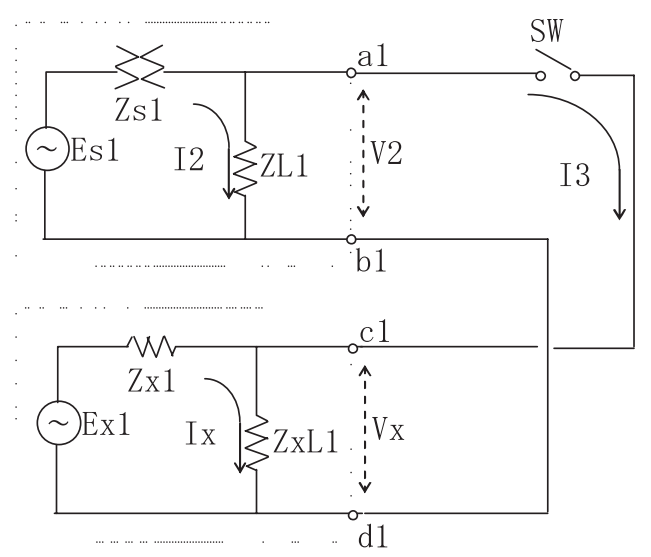

Es1：上位系統の電源

$\mathrm{Zs} 1 ： \mathrm{M}$ 変電所バンクのインピーダンス

ZL1：M 変電所バンク以下の負荷インピーダンス

Ex1：異系統側の電源

$\mathrm{Zx} 1$ ：異系統側の送電線インピーダンス

$\mathrm{ZxL1}$ ：異系統側の負荷インピーダンス

Fig. 4. Equivalent circuit model (case of generator parallel in).

\section{4. 特異現象の発生メカニズムの推定}

VT が何らかの原因で飽和したのであれば，電圧のみ低 下寸る可能性がある。

また，近年，複数箇所で同じ現象が発生しており，同時 期に $77 \mathrm{kV}$ 系統で急速に整備を拡大してきている送電線ア レスタが影響しているものと考え, 発生メカニズムを下記 のと扔り推定した。

(1) 当該系統の送電線への直撃雷が発生

(2) 送電線アレスタの制限電圧以下の雷撃エネルギーが 直流分としてVTに供給

(3) 直流分によってVTが飽和し, VT二次電圧低下

(4) 連続放電により VT 飽和が継続し，VT二次電圧低 下が継続

$\langle\mathbf{4} \cdot \mathbf{1}\rangle$ 直撃雷の発生 LLS の落雷記録を確認したと ころ, 現象発生と全く同時刻に, 当該系統の送電線に, 落 雷の実績が記録されていた (Table 1 参照)。落雷の記録が あった箇所を Fig. 2 に落雷想定箇所として示す。

一方，落雷記録があった送電線の設備状況を調査したと ころ, アレスタが設置されていた。このため, 当該線路に 落雷が発生した時, アレス夕により雷撃電流が除去され, 保 護リレーが動作しなかったものと想定した。

また, 落雷には, 直撃雷と誘導雷 (架空地線への落雷によ る逆フラッシュオーバー) があるが，EMTPによるシミュ レーションの結果, 誘導雷では, 送電線へ印加される電圧 が小さいため，VTを飽和させるだけの十分なエネルギー は供給されないことが確認できたため，現象の起因は直撃 雷と推定した。

〈4・2〉 アレスタ動作による VTへの直流分供給 ア レス夕非設置送電線へ落雷があった場合，アークホーンが 動作しほとんどの雷エネルギーが大地に流れ，その後保護 リレーも動作することから，VTへ雷から大きなエネルギー が供給されることはない。

一方，アレス夕設置送電線では，アレスタ制限電圧以下

Table 1. Lighting stroke recorded in LLS.

\begin{tabular}{|c|c|c|c|}
\hline \multirow{2}{*}{ time } & \multicolumn{2}{|c|}{ Point of lighting stroke } & \multirow{2}{*}{$\begin{array}{c}\text { Current of } \\
\text { Lighting stroke }\end{array}$} \\
\cline { 2 - 3 } & Longitude & Latitude & $14.6 \mathrm{kA}$ \\
\hline $17: 32: 36.591$ & 137.188 & 35.425 & $9.5 \mathrm{kA}$ \\
\hline $17: 32: 36.939$ & 137.175 & 35.381 & \\
\hline
\end{tabular}

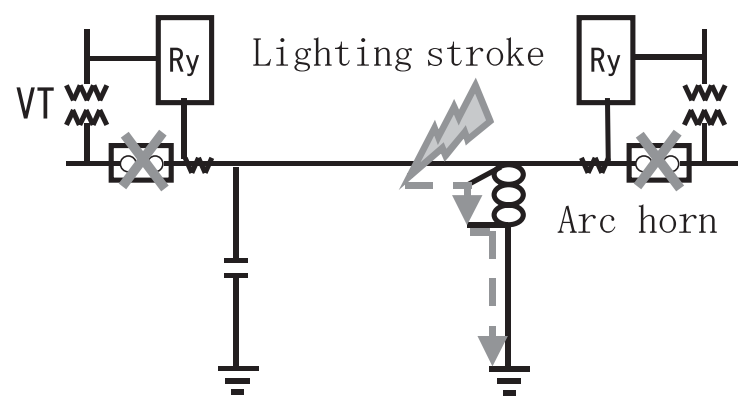

Fig. 5. Lightning stroke to the line without arrester. 


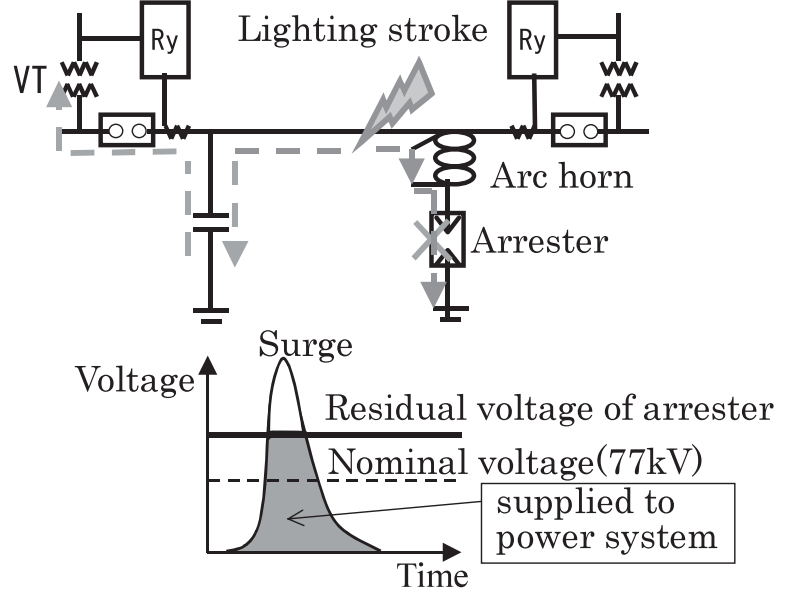

Fig. 6. Lightning stroke to the line with arrester.

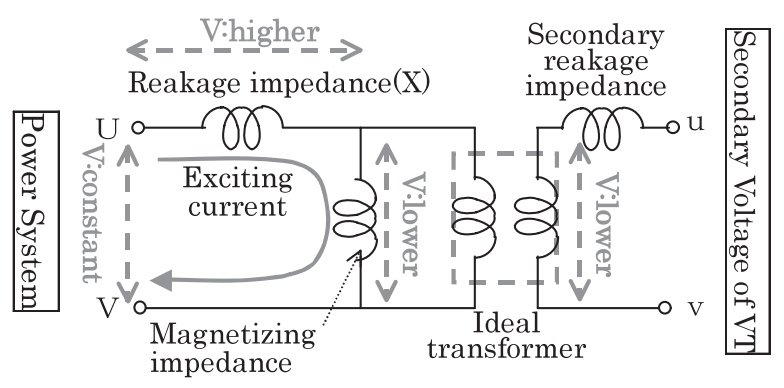

Fig. 7. Equivalent circuit of VT.

のエネルギーは，直流分として系統へ供給される。

系統に供給された直流分は，系統の静電容量分に一旦蓄 えられ系統の零相 CR 並列回路を通じて NGR (中性点接地 抵抗）やVT中性点を通して徐々に放電していくものと考 えられる。

$\langle\mathbf{4} \cdot \mathbf{3}\rangle$ 直流分による VT 飽和と二次電圧低下 VTは, 電力用変圧器等と比較して, 一次側漏れインピーダンスが 非常に大きく，鉄心が飽和した場合に二次側電圧が低下し やすい特徴がある。

一次漏れインピーダンスが大きい理由は, 一次側コイル と二次側コイルの巻数比が大きく，一次側コイルの巻数が 非常に多いことである。また，鉄心のサイズが小さいこと からも，鉄心の磁束密度を低くする目的で，巻数を増やす 必要がある。

なお, 一般の $77 \mathrm{kV}$ クラスの電力用変圧器の漏れインピー ダンスは $7.7 \%$ (配電用変圧器) 程度で, リアクタンス換算 は約 $120 \mathrm{mH}$ である。一方今回対象の $77 \mathrm{kVVT}$ のアアタ ンスは $100 \mathrm{H}$ 程度と言われており，約 800 倍も大きい。

Fig. 7 には，VTの等価回路を示すが，UV間に直流分が 流入して鉄心が飽和すると，励磁インピーダンスが小さく なる。この時，一次漏れインピーダンスが大きいと，VT2 次側の電圧低下が大きくなる。

〈4·4〉連続放電による電圧低下継続＼cjkstart本現象は，10 サイクル程度電圧低下が継続しているが，EMTPによるシ

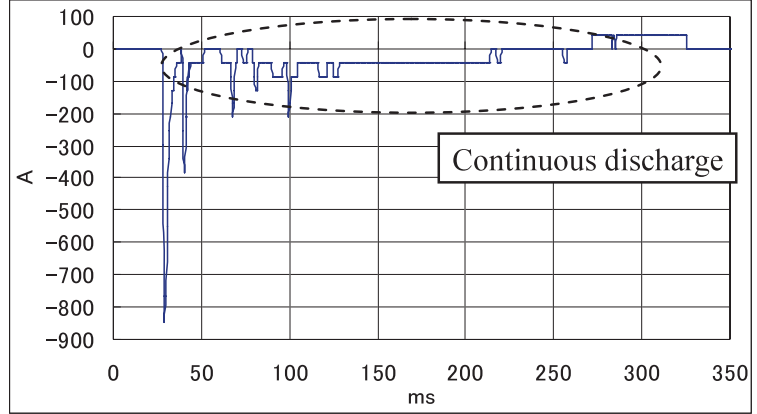

Fig. 8. NGR current - Fault recorder (S Substation).

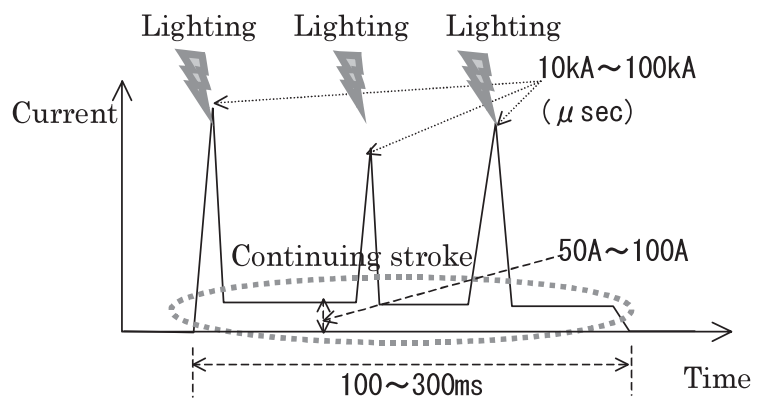

Fig. 9. Continuous discharge.

ミュレーションの結果，〈4·2〉節で説明した系統の静電容 量分に蓄えられた直流分の放電だけでは，電圧低下は2 3 サイクルしか継続しないことが分かった。

しかし，M変電所の自動オシロ装置が記録した NGRの 電流からは, 連続して直流分が供給されたことが確認でき た (Fig. 8 参照)。

また, 現象発生時に多数の雷が発生していたことから，こ の直流分は, “連続放電”により供給されたものと推定した。 連続放電 ${ }^{(1)}$ とは, 多重雷が発生している状況で, 最初の 雷撃が終止した後, 次の雷撃が生ずるまでの間, $100 \mathrm{~A}$ 程度 の小さい電流が数百 $\mathrm{ms}$ 継続する事象である (Fig. 9 参照)。

この連続放電により，ある程度継続して直流が供給され VT 飽和による電圧低下が継続したと推定した。

5. EMTP（ATP 版）シミュレーション

〈5・1〉 シミュレーション条件シミュレーションで 使用したVT, アレス夕, 送電線, NGR どの設備モデル には，全て実際の設備定数を収集して入力した。

本書へのこれら全ての定数の記載は省略するが, 本現象へ の関わりが大きい送電線アレスタの V-I 特性を Fig. 10 に, VT の励磁特性を Fig. 11 に示す。

$\langle\mathbf{5} \cdot \mathbf{2}\rangle$ 変電所へ侵入する雷撃エネルギーの試算

落雷想定箇所の送電線と変電所母線のみをモデル化し て,「直撃雷」と「架空地線落雷」時のVTへ侵入するエネ ルギーを試算し, 直撃雷の可能性が高いことを確認した。

シミュレーションモデルは, 落雷想定箇所の送電線（架 空地線）と変電所母線のみをモデル化し, 雷源は, LLS 記 


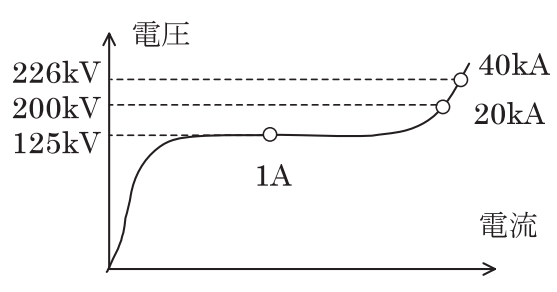

Fig. 10. V-I characteristic of line arrester.

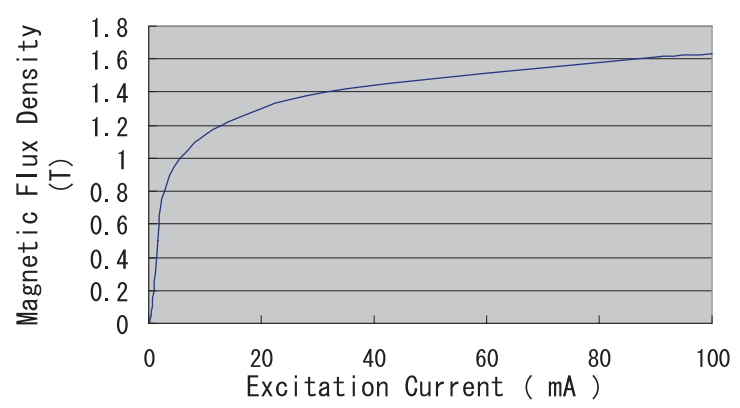

Fig. 11. Excitation characteristic of VT.

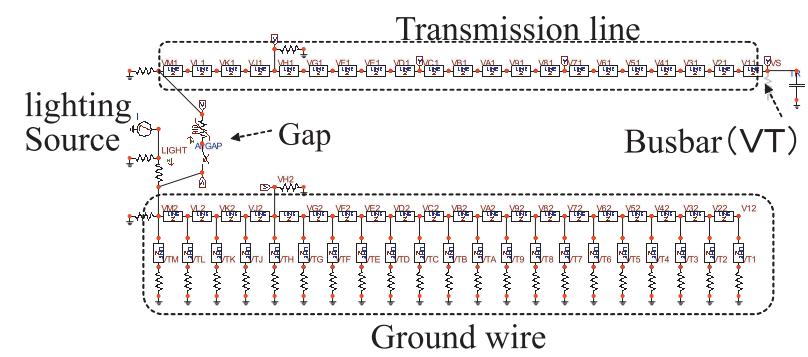

Fig. 12. EMTP simulation model; Section $\langle 5 \cdot 2\rangle$.

\section{録から $10 \mathrm{kA}$ とした。}

ケース $1:$ :直撃雷」とケース $2:\lceil$ 架空地線への落雷」で 検証を行った結果，ケース 2 では，運転電圧程度の電圧し かVTに進入しないため, 直撃雷でなければ本現象は発生 しにくいことが確認できた (Fig.13 参照)。

〈5・3〉実系統モデルによる現象再現＼cjkstart実系統モデル を作成して, 実現象の再現を行った。落雷想定箇所には, 雷 源として電流源を設置した。

（1）単発の落雷のケース連続放電ではなく，単発 の落雷を想定したシミュレーション結果を Fig. 15 に示す が，2〜3サイクルしか電圧低下が継続しないことが確認で きる。

（2）連続放電のケース 自動オシロ装置で記録され た NGR 電流は, 電流值が小さいことから, CT 飽和のない 正確な波形と考えられる。そこで, EMTPでは, 複数の電 流源を組み合わせて雷源を構築し，EMTP モデルの NGR 電流波形が自動オシロの NGR 電流波形と合致するよう調 整した。Fig. 16 の左側に実測波形，右側に EMTP モデル の NGR 電流波形を示すが，実測オシロのステップ状の変 化に対し， EMTPで指数関数モデルを使用していることか ら，様相が完全に一致していないが，ここでは，100 ms 程

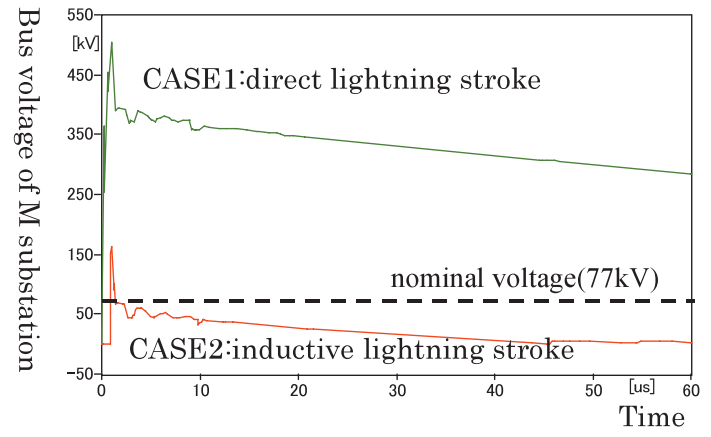

Fig. 13. Test calculation of lighting energy.

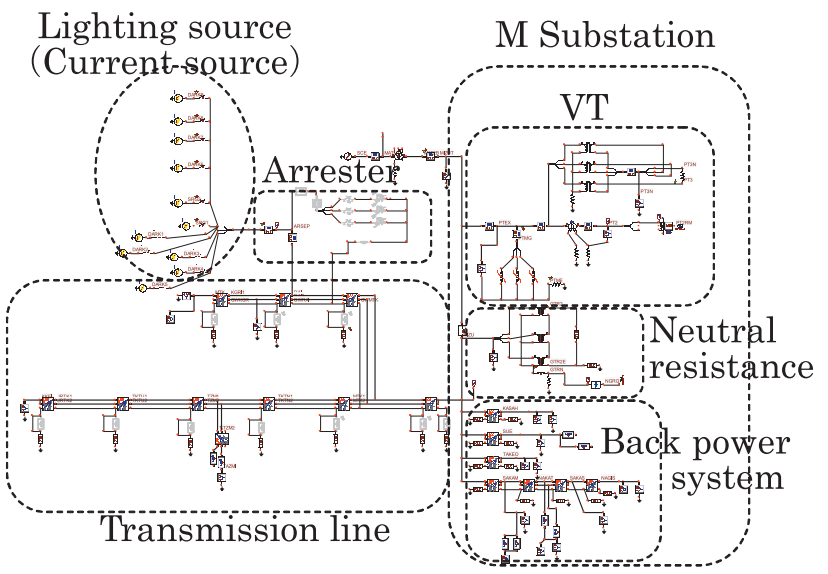

Fig. 14. EMTP simulation model Section $\langle 5 \cdot 3\rangle$ (M Substation).

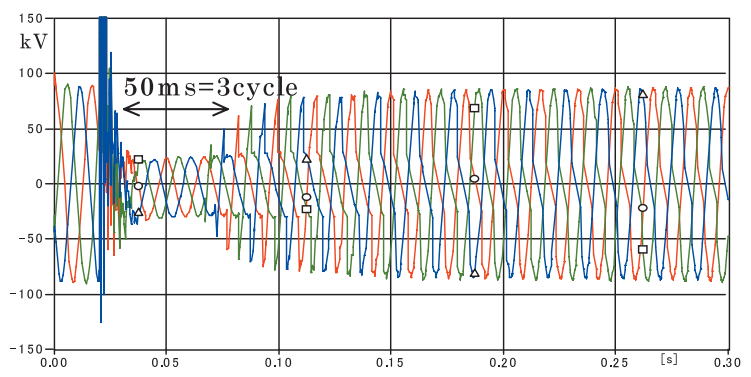

Fig. 15. Bus-bar Voltage-EMTP (M Substation).

度継続する電圧低下の再現を対象としているため, 全体の 変化の様子が，概ね合致するよう調整している。

自動オシロ装置が記録した $77 \mathrm{kV}$ 母線電圧の波形と, EMTP シミュレーションによって再現した電圧の波形を Fig. 17 に示すが, $100 \mathrm{~ms}$ 程度電圧低下が継続する現象が再 現できて㧍り，推定要因の妥当性が確認できた。

なお， $200 \mathrm{~ms}$ 以降の電圧低下の回復過程が，幾分異なっ ているが, EMTP モデルの背後系統について，時定数が実 系統と完全に一致していないためと考えられる。

また, $\mathrm{S}$ 変電所に発生した現象に対しても, 同様のシミュ レーションを行った。自動オシロ装置が記録した $77 \mathrm{kV}$ 母 線電圧の波形と, EMTP シミュレーションによって再現し た波形を Fig. 18 に示すが，ここでも，ほぼ実測值に近い現 
$<$ Fault recorder $>$

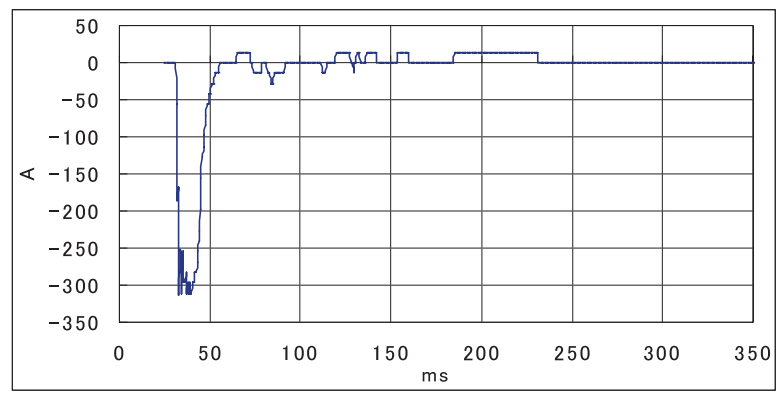

$<$ EMTP $>$

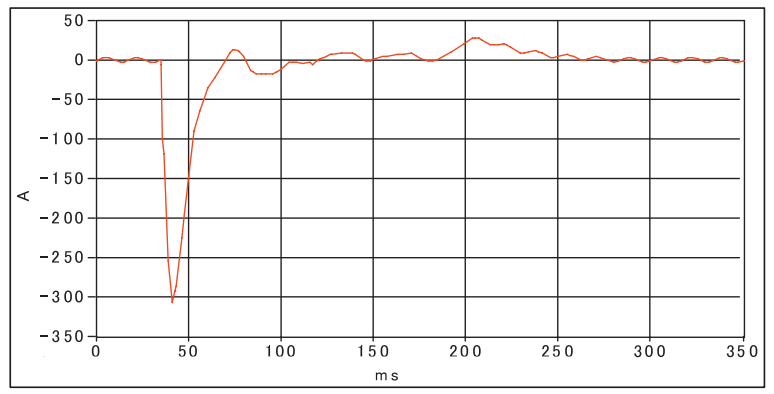

Fig. 16. NGR current (M Substation).

$<$ Fault recorder $>$

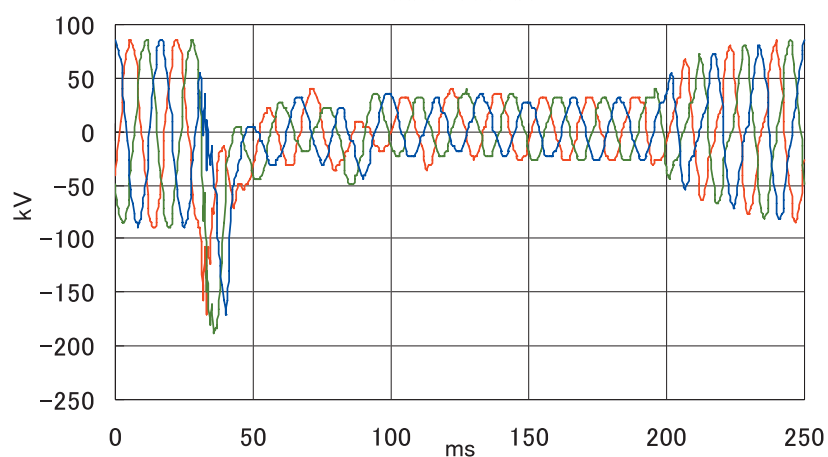

$<$ EMTP $>$

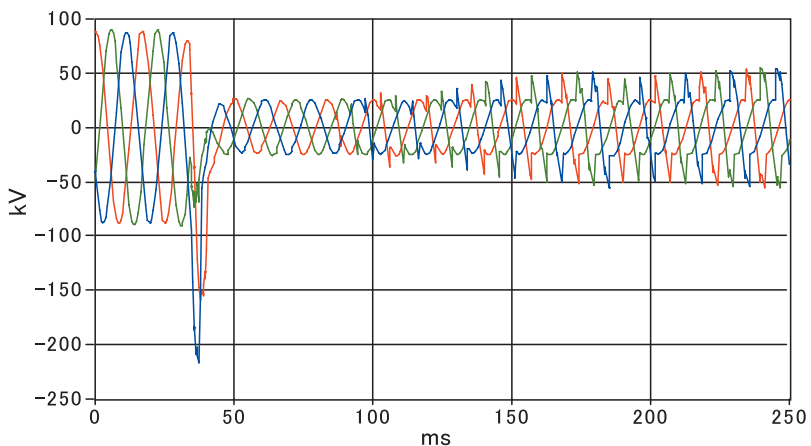

Fig. 17. Bus-bar voltage (M Substation).

$<$ Fault recorder $>$

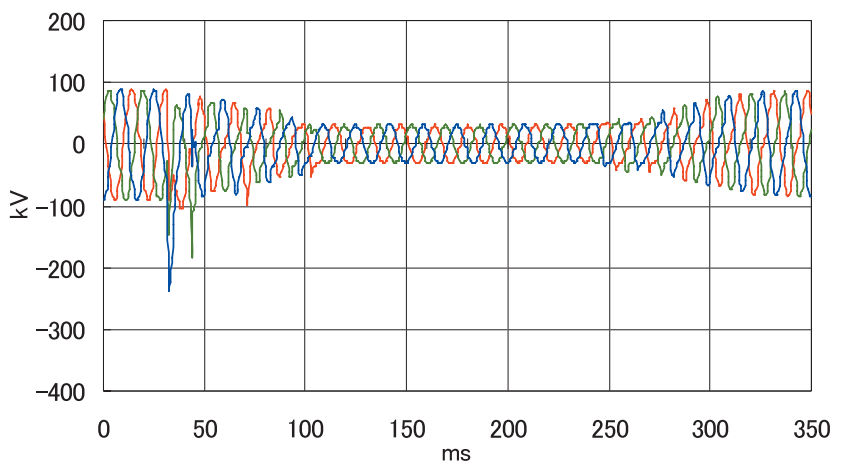

$<$ EMTP $>$

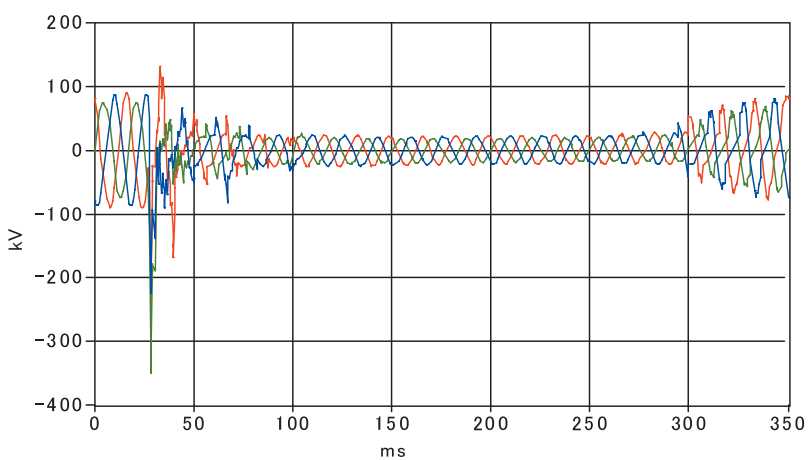

Fig. 18. Bus-bar voltage (S Substation).

象が再現でき，推定要因の妥当性が確認できた。

\section{6. 保護リレーへの影響}

〈6・1〉影響範囲送電線用アレスタは $154 \mathrm{kV}$ 以下系 統に適用しているため, $154 \mathrm{kV}$ 以下系統に適用している保 護リレーを対象に評価した。

$\langle\mathbf{6} \cdot 2\rangle$ 短絡保護 VT 二次側電圧が低下することか ら，電流差動継電方式のフェールセーフリレーである電圧 低下リレーと，方向距離継電方式のメインリレーである距 離リレーが, 誤動作する可能性があるが，メインリレーと ストッパーリレーが同時に動作して誤遮断に至ることはな い (Table 2 参照)。

ただし，方向距離継電方式に関して，VT 飽和によって距 離リレーが動作している間に，連続雷撃によって，フェー
Table 2. Possibility of mal-operation by VT saturation.

\begin{tabular}{|c|c|c|c|}
\hline \multirow{2}{*}{$\begin{array}{c}\text { Short circuit } \\
\text { protection Method }\end{array}$} & \multicolumn{2}{|c|}{ Relay } & \multirow{2}{*}{ Trip } \\
\cline { 2 - 3 } & Main & Failsafe & \\
\hline Differential Current & $\times$ & $\bigcirc$ & $\times$ \\
\hline Over Current & $\times$ & $\times$ & $\times$ \\
\hline Transverse Differential & $\times$ & $\times$ & $\times$ \\
\hline Directional Distance & $\bigcirc$ & $\times$ & $\times(※)$ \\
\hline
\end{tabular}

$\bigcirc$ : Possibility of operation by VT saturation

$X$ : No possibility of operation by VT saturation

$※$ : Possibility of mis-trip if a system fault occurs while VT saturation

ルセーフリレーの電流変化幅リレーが動作するような系統 故障が発生すれば，保護範囲外の故障であっても誤遮断す 
る可能性がある。しかし，保護機能が失われる訳ではなく， 極めて希なケースであるため, 想定外の故障として扱うこ とができると考える。

$\langle 6 \cdot 3\rangle$ 地絡保護 本現象での Vo, Io は，直流分もし くは高調波成分のみが発生しているため, 保護リレーが誤 動作する可能性はないと考えられる。

\section{7. まとめ}

本稿では, 中部電力管内変電所にて発生したVT 飽和に伴 う電圧低下現象の発生メカニズムを推定し，EMTP シミュ レーションにて現象の再現を行うことで，その妥当性を確 認することができた。

近年, 送電線アレス夕の整備が搪大してきているため, 今 後，同様の現象が発生する機会は増えてくるものと思われ る。しかし，本稿にて，発生原因の究明と保護リレーへの 影響評価を実施した結果，系統運用へ大きな支障がないこ とを明らかにすることができた。

今後の課題として, 本現象が確認された場合は送電線に 直撃雷があった可能性が高いため, 送電線巡視の判断指標 に活用することを検討していきたい。

(平成 21 年 3 月 24 日受付, 平成 21 年 9 月 12 日再受付)

\section{文献}

(1) 電気学会：電気工学ハンドブック第 6 版 (2001-1)

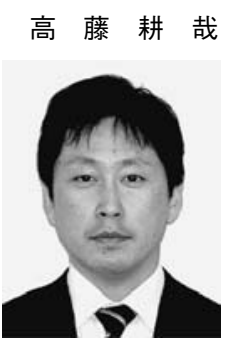

（正員） 1972 年 5 月 6 日生。1996 年 3 月広島大 学大学院工学研究科システム工学専攻修士課程修 了。同年 4 月中部電力（株）入社，現在に至る。 主として, 電力系統の保護制御装置の開発・計画, 系統安定化システムの開発・計画に従事。

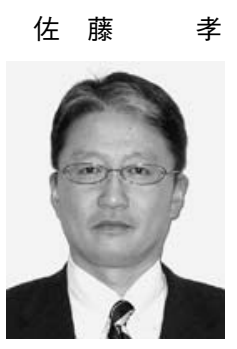

(正員) 1962 年 8 月 8 日生。 1983 年 3 月長野工 業高等専門学校電気工学科卒業。同年 4 月中部電 力 (株) 入社, 現在に至る。主として, 電力系統 の運用, 系統安定化システムの開発・計画に従事。

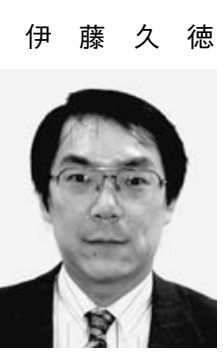

（正員） 1962 年 4 月 27 日生。1985 年 3 月東京 工業大学工学部電気電子工学科卒業。同年 4 月中 部電力 (株) 入社, 現在に至る。主として, 電力 系統の保護制御装置の開発・計画, 系統安定化シ ステムの開発・計画に従事。1996 年電気学会進歩 賞受賞。

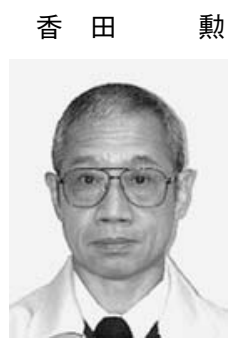

（正員） 1945 年 4 月 22 日生。1964 年 4 月中部 電力 (株) 入社。 2003 年 (株) 中電シーティーア イ出向, 現在に至る。主として, 電力系統の保護 制御装置の開発，保守，系統解析に従事。

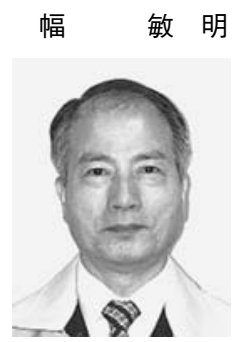

(非会員) 1936 年 10 月 20 日生。 1955 年 4 月中 部電力 (株) 入社。1993 年 (株) 中電シーティー アイ出向。2008 年同社退社。主として, 給電業 務, 自動給電システムの開発業務, 系統解析業務, 関連ソフト開発業務に従事。1974 年電気学会論 文賞, 1983 年電気学会進歩賞受賞。

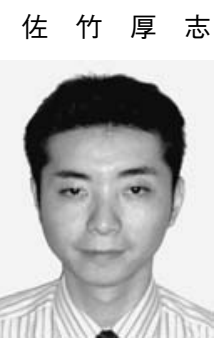

（正員） 1978 年 6 月 15 日生。 2003 年 3 月中部 大学大学院工学研究科電気工学専攻修士課程修了。 同年 4 月（株）中電シーティーアイに入社，現在 に至る。主として，系統解析業務に従事。

萩 森 英 - (正員) 1940 年 1 月 2 日生。1962 年 3 月東京

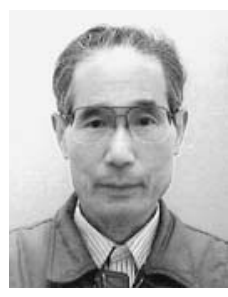
工業大学理工学部卒業。同年 4 月（株）東芝入 社。1991 年東京工業大学客員教授。1998 年九州 工業大学教授。2004 年中央大学兼任講師, 現在に 至る。工学博士。主として, 空気遮断器, ガス遮 断器開発設計に従事。IEC-SC17A-WG1, WG10, WG21, MT36 メンバーにて交流遮断器規格制定・ 改訂に従事。 